\title{
Watervliet Arsenal Decision Tree Program for Evaluating Hazardous Spills (SPILL)
}

Veda D. Scarpetta

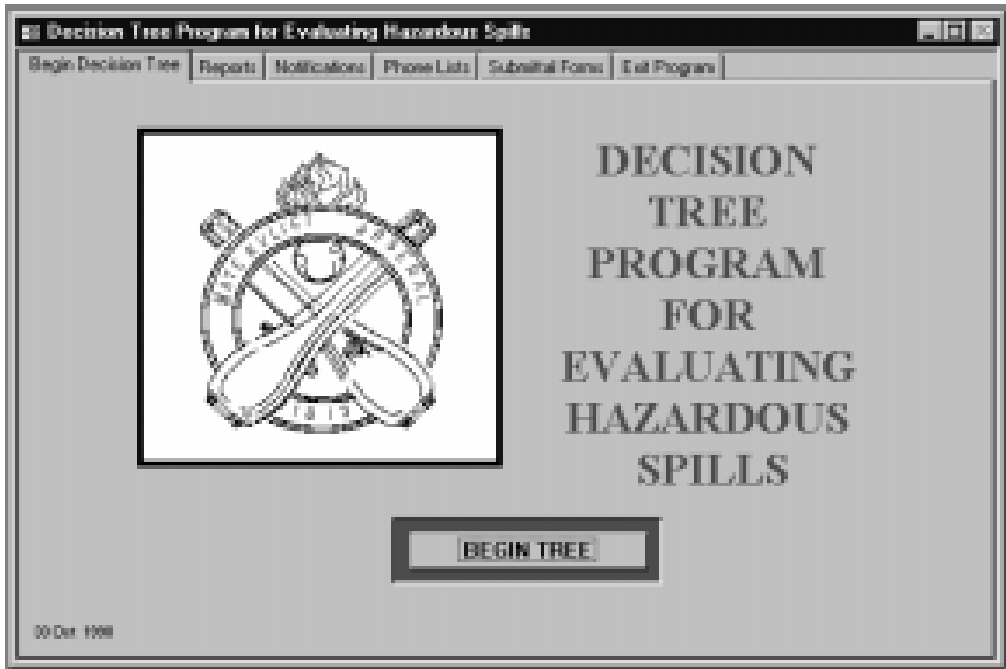

This study devised the Decision Tree Program for Evaluating Hazardous Spills (SPILL), a computer tool designed to allow Army installation personnel to evaluate a material spill on installation property and, based on determining factors, to report the event in a proper and timely fashion to all appropriate authorities. The program accomplishes the determination by presenting the user with a series of "YES" and "NO" questions regarding the spill. On conclusion of the question/answer segment, the program lists instructions and required notifications for the specific type of spill in question. SPILL also contains editable notification and phone lists.

While the SPILL program was created specifically to meet the needs of a single Army installation, it may help any installation that stores, handles, or uses hazardous materials to quickly and correctly evaluate and respond to hazardous materials spills. 


\section{Foreword}

This study was conducted for Watervliet Arsenal under MIPR No. 8DISCERL19X, "Decision Tree Program for Evaluation Hazardous Spills." The technical monitor was Dr. Dana L. Levy, SIOWV-ISH.

The work was performed by the F acilities Maintenance Branch (CF-F) of the Facilities Division (CF), Construction Engineering Research Laboratory (CERL). The CERL Principal Investigator was Veda D. Scarpetta. Many thanks are owed to J earldine Northrup, CECER-CN-E, for her valuable contributions as technical advisor to this project. Mark W. Slaughter is Chief, CECER-CF-F, and L. Michael Golish is Chief, CECER-CF. The technical editor was William J . Wolfe, Information Technology Laboratory.

The Director of CERL is Dr. Michael J . O'Connor. 


\section{Contents}

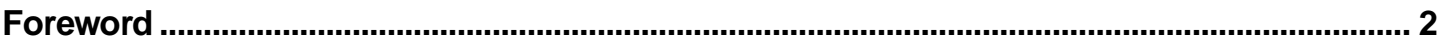

1 Introduction

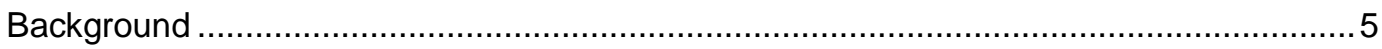

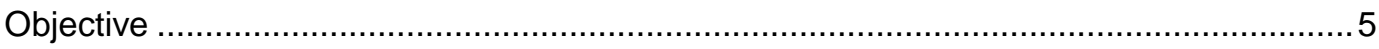

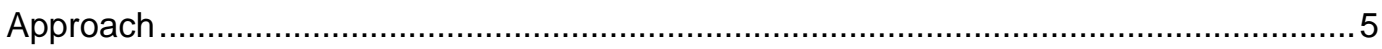

Scope

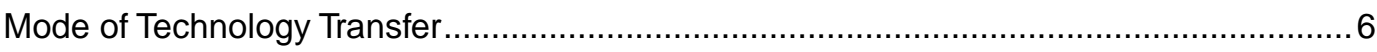

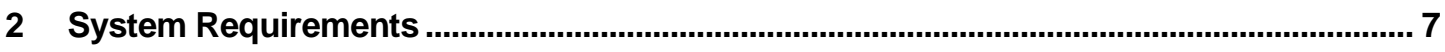

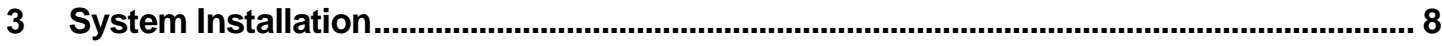

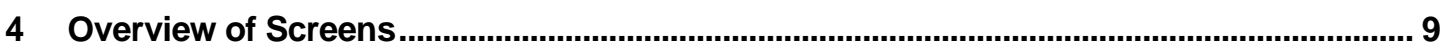

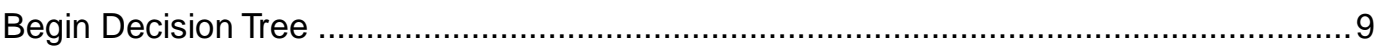

Reports

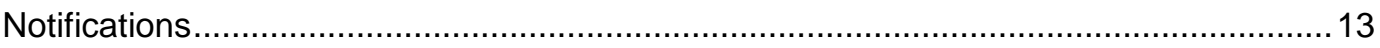

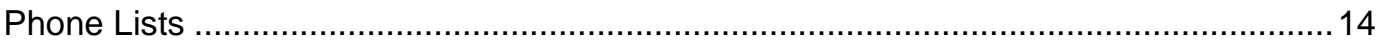

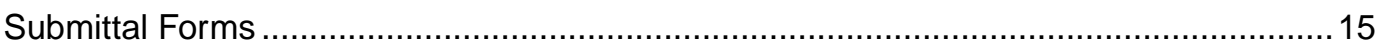

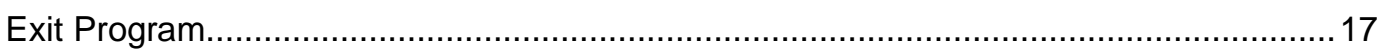

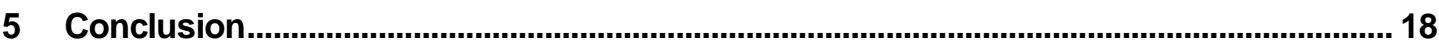

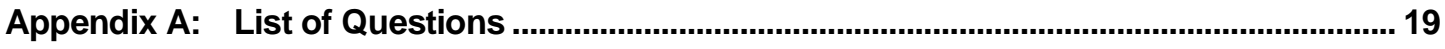

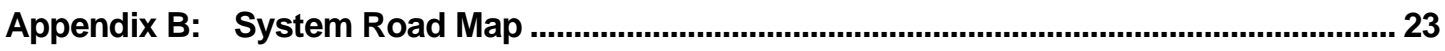

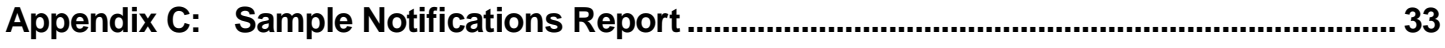

Appendix D: Sample Answer Trail Report ............................................................................... 37

Appendix E: Report of Noncompliance Event Form

DISTRIBUTION

REPORT DOCUMENTATION PAGE 


\section{List of Figures}

\section{Figures}

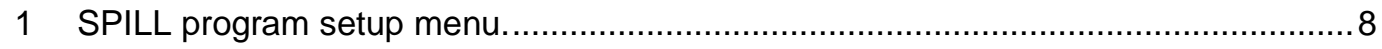

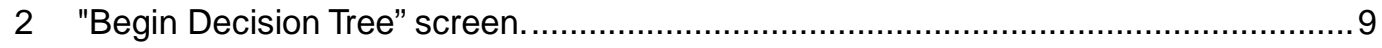

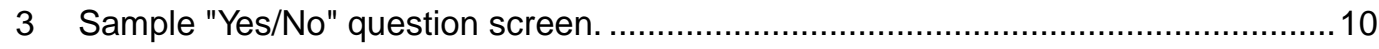

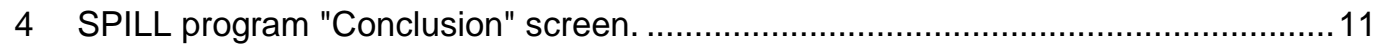

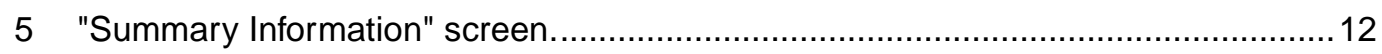

6 SPILL program "Reports" screen. ................................................................... 13

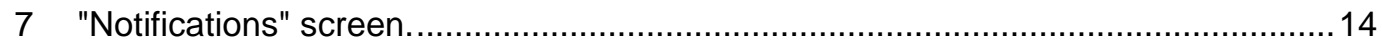

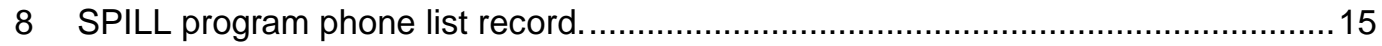

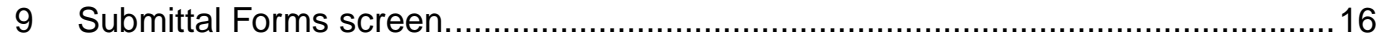

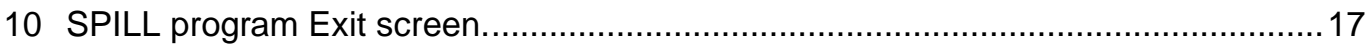




\section{Introduction}

\section{Background}

The Decision Tree Program for Evaluating Hazardous Spills (SPILL) is a computer tool designed to allow Watervliet Arsenal personnel to evaluate a material spill on installation property and, based on determining factors, to report the event in a proper and timely fashion to all appropriate authorities. The program accomplishes the determination by presenting the user with a series of "YES" and "NO" questions regarding the spill. There are many paths through the program. Not all questions are asked every time, only the ones pertinent to the current set of circumstances. On conclusion of the question/answer segment, the user will be presented with reports that list instructions and required notifications for the specific type of spill in question.

In addition to the decision tree portion of the program, SPILL also contains editable notification and phone lists. The program also provides a facility for printing out the N ew York State Department of Environmental Conservation Division of Water "REPORT OF NONCOMPLIANCE EVENT" form.

\section{Objective}

The objective of this study was to devise an automated approach to help Army installation personnel quickly and correctly evaluate hazardous materials spills, and make required notifications.

\section{Approach}

1. Definitions of hazardous materials, and notification requirements for hazardous materials spills were reviewed.

2. A series of Yes/No questions was derived to determine, according to specific determining factors, whether a specific spill invol ved hazardous material(s), and whether notification(s) were required.

3. The question/answer series was programmed into a user-friendly, menu-driven MS Access data base program. 
4. The data base program was also programmed to include editable notification and phone lists so users can update the program to meet current needs.

\section{Scope}

While the SPILL program was created specifically to meet the needs of a single Army installation, it may help any installation that stores, handles, or uses hazardous materials to quickly and correctly evaluate and respond to hazardous materials spills.

\section{Mode of Technology Transfer}

The SPILL program was sent directly to its sponsoring agency. It is anticipated that the SPILL manual and application will be made available for download from the CERL Internet web page, accessible through the URL:

http://www.cecer.army.mil/ 


\section{System Requirements}

The SPILL program was developed using Microsoft ${ }^{\circledR}$ ACCESS $^{\circ}$ 97. Microsoft ACCESS is a Relational Data Base Management System (RDBMS) with a builtin visual basic programming capability. SPILL requires approximately 6.5 megabytes of disk space as well as at least 12 megabytes of RAM under Windows 95 or 16 megabytes under Windows NT. It is also intended for use with monitors having VGA resolution. If the SPILL program is used with super VGA resolution, it may not fit properly on the computer screen. 


\section{System Installation}

To install the SPILL program to the hard drive on your computer, load the installation CD into your CD drive. Run the SETUP.EXE program from the CD to begin the installation. The default installation directory is $\mathrm{C}: \mathrm{I}$ spill, but you may change this at setup time (Figure 1). A "Hazardous Spill Decision Tree" item will be added to the Windows Programs menu at the conclusion of the installation process. Click on the SPILL menu item to start the program.

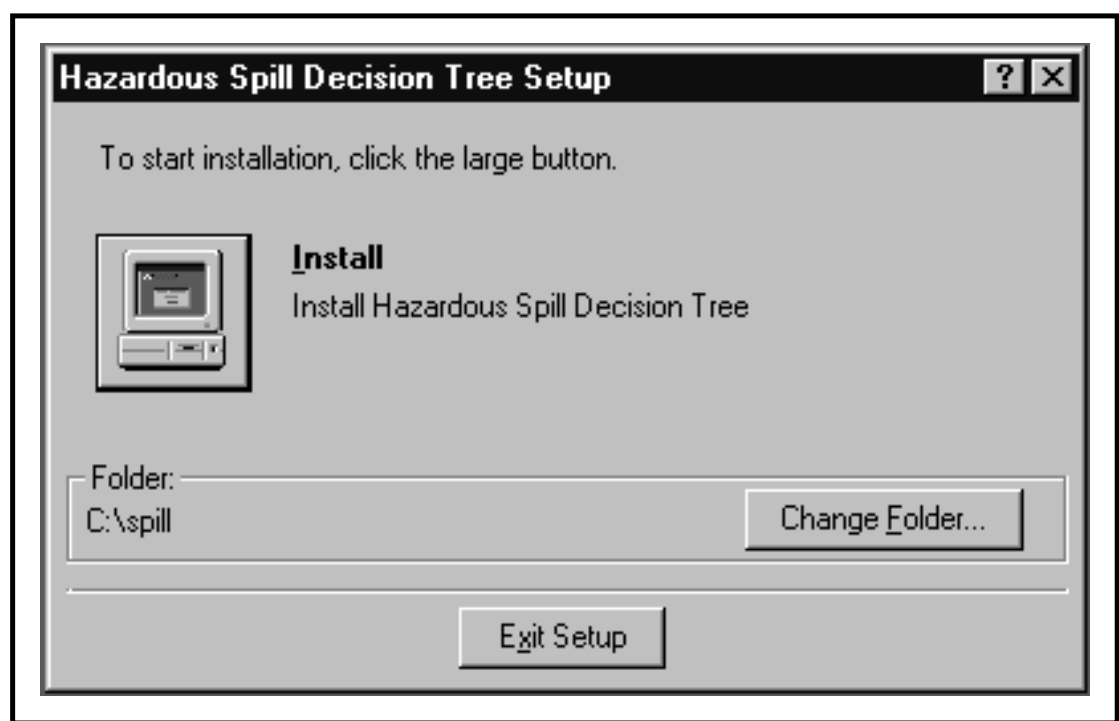

Figure 1. SPILL program setup menu. 


\section{Overview of Screens}

The program interface is segmented into six tabbed screens. The tabs are labeled "Begin Decision Tree," "Reports," "Notifications," "Phone Lists," "Submittal Forms," and "Exit Program." To select a screen, simply left-mouse click on the appropriate tab. The use of each of these six screens will be detailed below. The "Begin Decision Tree" screen (Figure 2) is displayed first.

\section{Begin Decision Tree}

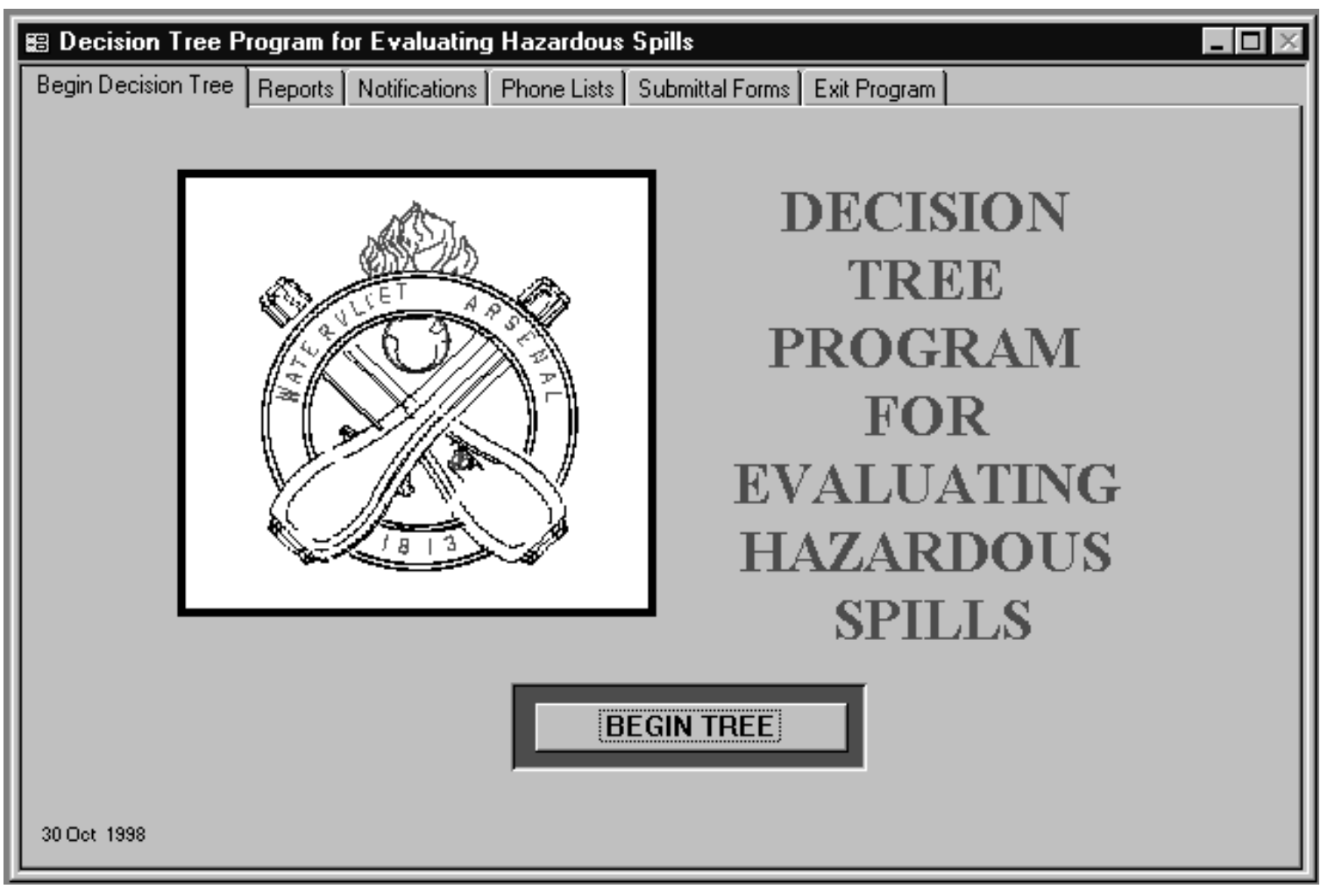

Figure 2. "Begin Decision Tree" screen.

Click the "BEGIN TREE" button to begin the question/answer session. The series of questions are organized into eleven blocks, labeled A, B, C ... through $\mathrm{K}$. (Blocks G, H, and K are currently unavailable, but could be added at a later date.) Depending upon how each question is answered, another question may 
follow. Do NOT be concerned if some questions are skipped. Answering YES or NO to particular questions may trigger a NOTIFICATION statement. When the program concludes, the program will create a report listing all the notifications that apply to the specific spill event. The user should follow the instructions in the notifications so all the appropriate authorities will be notified of the situation.

Appendix A to this letter report lists the text of each question in the system. Appendix B gives a "road map" showing how the questions are organized, and the sequence the questions will follow depending on specific YES or NO answers. This list also shows which NOTIFICATIONS the given answers will trigger.

Figure 3 shows a sample question screen. For each question screen, the user must mouse-click the YES or NO button, then dick the NEXT SCREEN button. On some screens, there is a PREVIOUS SCREEN button, which can be used to return to the previous screen. A user may back up through screens in the current question block, but may not return to a previous block. The block label appears in the bottom left corner. This screen shows Question \#18 in Block C.

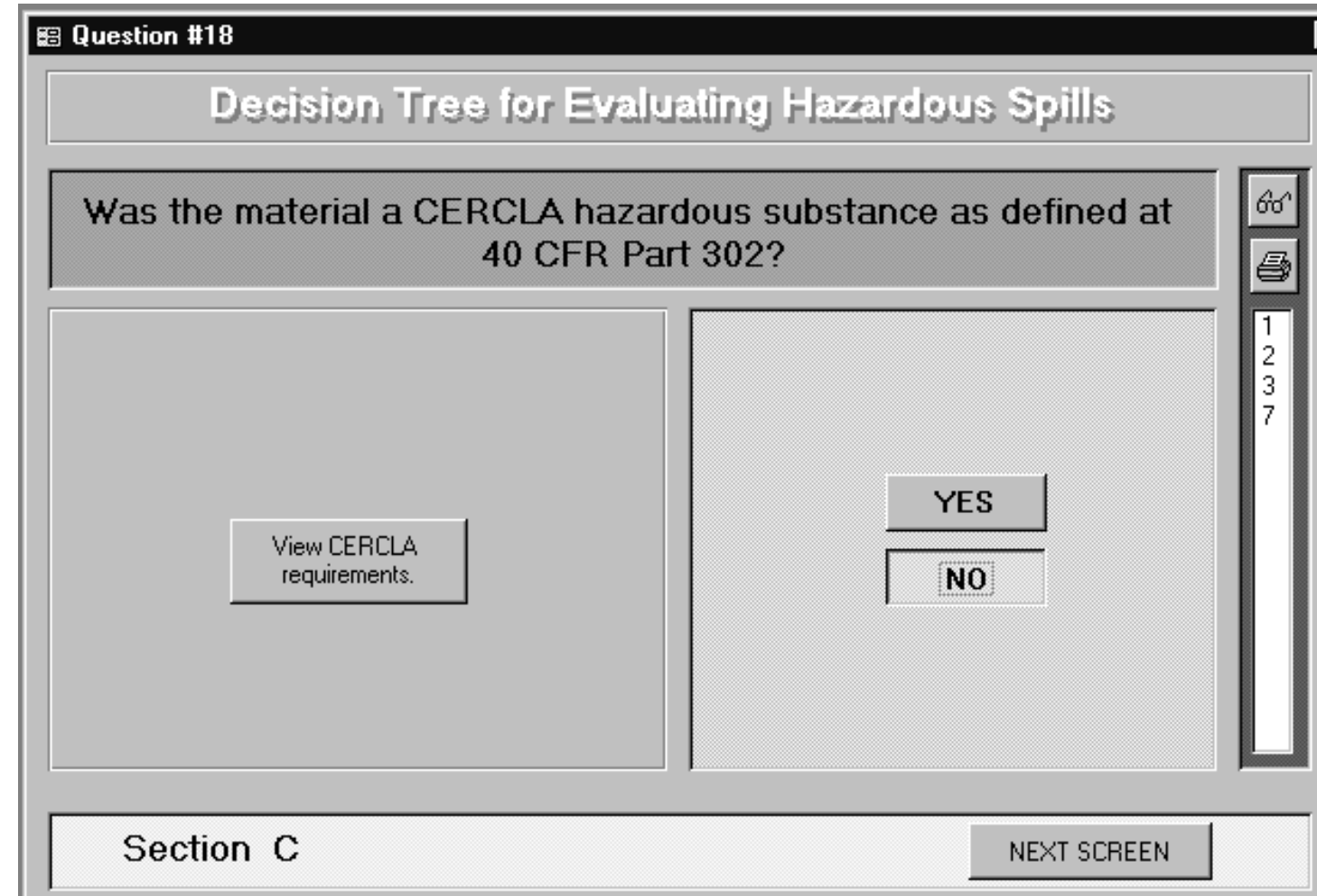

Figure 3. Sample "Yes/No" question screen. 
The vertical bar displayed on the right lists the notifications that apply to this spill event. This list may grow depending on how subsequent questions are answered. When the program concludes, all the applicable notifications will be listed in the final report. The user may view one of the notifications at this point by double-clicking on the notification number. For example, double-clicking on the 7 above will display notification \#7. The user may click on the "eyeglasses" button to view all the notifications in the list, or click on the "printer" button to print all of the notifications in the list.

Once the user has answered all the questions, the conclusion screen (Figure 4) is displayed. From this screen, the user has three options: (1) to view a list of notifications, (2) to print a list of notifications, and (3) to print an answer trail report. The answer trail report is a record of how each question was answered in the session just concluded.

\section{Conclusion}

\section{DECISION TREE PROGRAM FOR EVALUATING HAZARDOUS SPILLS}

\section{CONCLUSION}

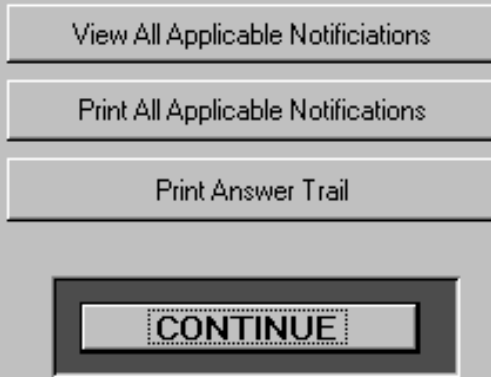

Figure 4. SPILL program “Conclusion” screen. 
When the "Print Answer Trail" button is selected, a "Summary Information" screen (Figure 5) appears that allows the user to document and label this spill session. It is recommended that the user complete this form and print the reports at this point. Otherwise, once the program is exited, these results will be lost.

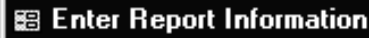

\section{Decision Thee for Evalualing Hezka dous Soills}

Provide the Summary Information that will appear in this Report:

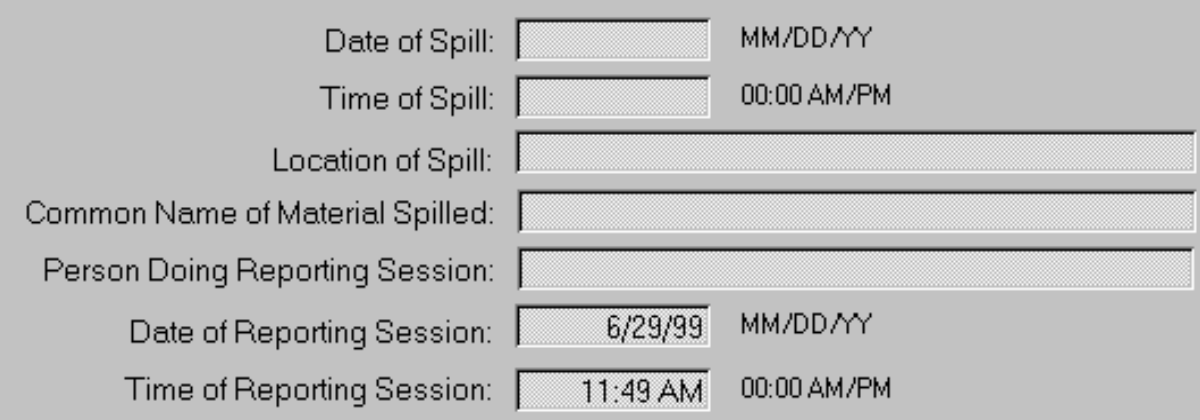

Figure 5. "Summary Information” screen.

\section{Reports}

Figure 6 shows the reports screen. This screen is another place from which the concluding reports may be produced. Keep in mind that these reports are available ONLY until the program is exited or until a new question/answer session is begun. 


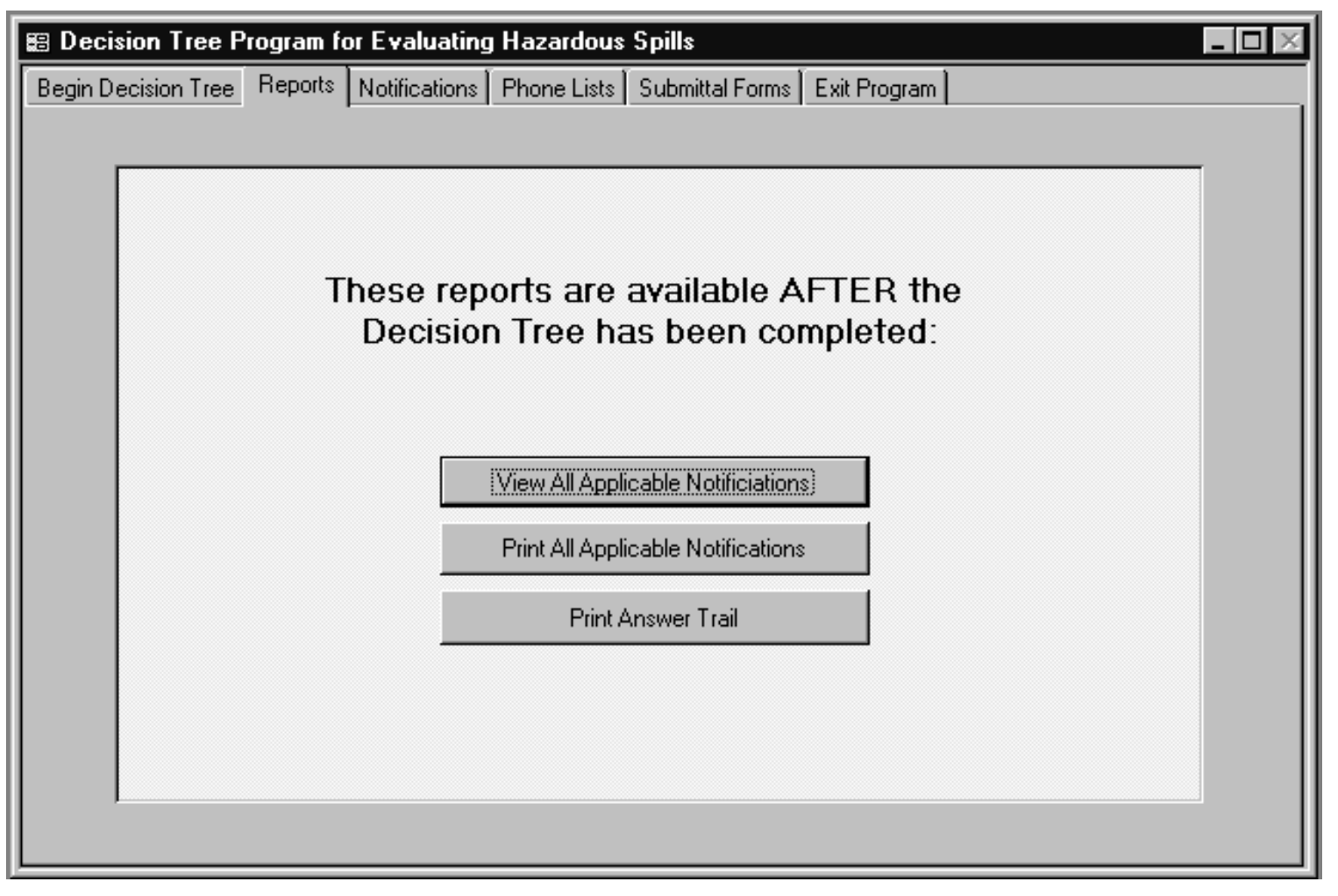

Figure 6. SPILL program "Reports" screen.

A sample notification report is included in Appendix $C$ and a sample answer trail report is included in Appendix D.

\section{Notifications}

The "road map" in Appendix B shows how the notifications are programmatically tied to the questions and answers. (F or example, answering "Yes" to Question 3 triggers Notification \#1.) This link is hard-coded and cannot be easily changed. However, the text of each notification is editable. There will be times that phone numbers and names will need to be changed. This notification list is edited by using the NOTIFICATIONS screen (Figure 7). 


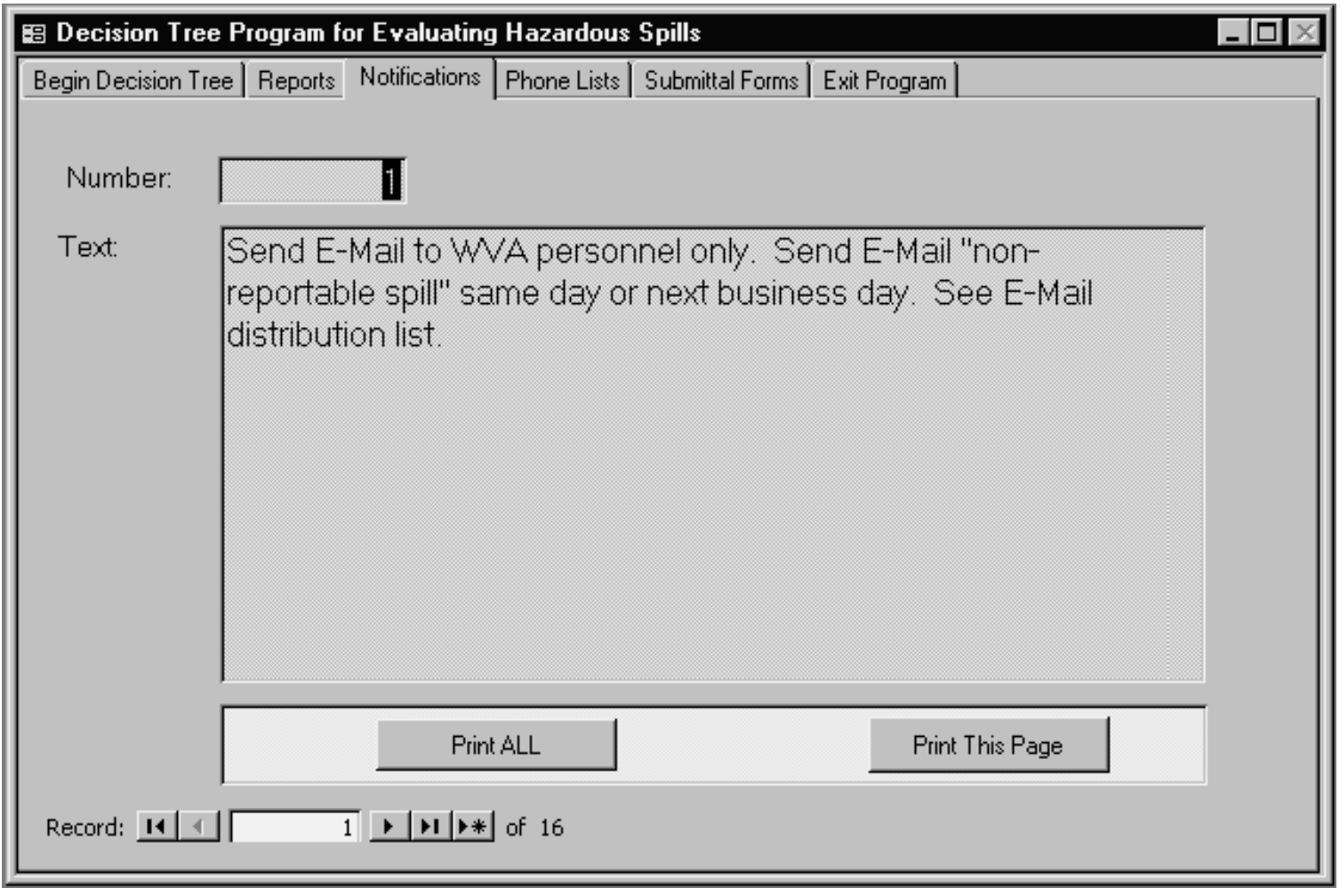

Figure 7. “Notifications” screen.

Each notification is keyed to the NOTIFICATION number. To change the text, simply type over it. Once changed, this new information is saved "permanently" or until it is changed again. The current notification may be printed by clicking the "Print This Page" button. Use the "Print ALL" button to print all notifications in the system.

\section{Phone Lists}

The phone list feature is not directly attached to the notifications or to other parts of the program, but is provided as a convenience. The user will want to add all pertinent phone numbers to the list so that they will be readily accessible during a spill situation. 


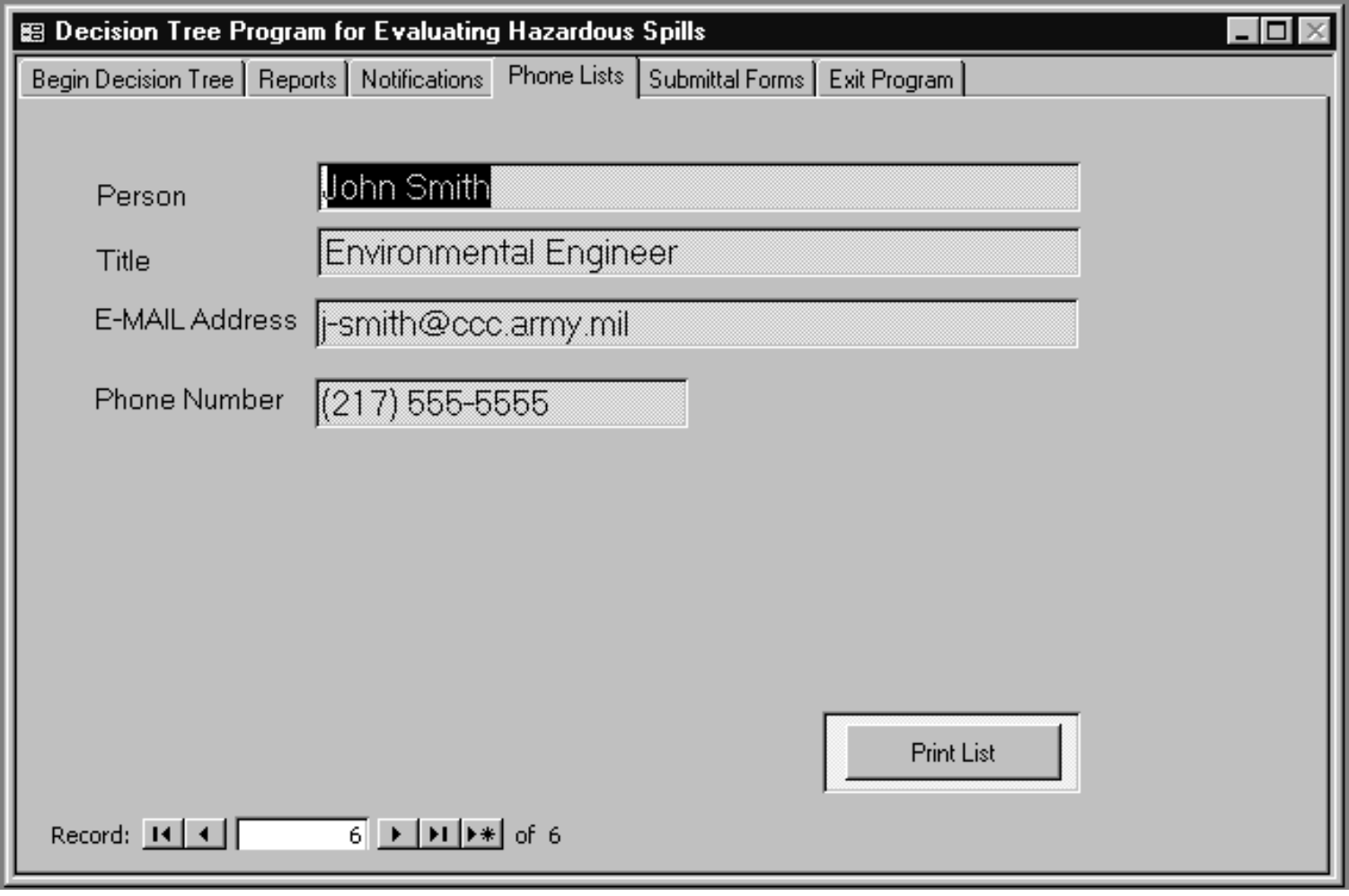

Figure 8. SPILL program phone list record.

To edit a record, simply type over the existing text. It will be saved and remain as such until it is edited again.

To add a new record, mouse click on the button. A new blank record appears. Type in the information for the new record.

A complete phone "directory" may be printed by using the "Print List" button.

\section{Submittal Forms}

On conclusion of the decision tree sequence for a specific spill, one of the notification statements may stipulate that a New York State Department of Environmental Conservation Division of Water "REPORT OF NONCOMPLIANCE EVENT" be submitted. The user may produce a copy of this noncompliance from the submittal forms screen (Figure 9). Appendix $\mathrm{E}$ to this letter report contains a copy of this form. The instruction sheet for completing this form may also be printed from this screen. Print either of these items by clicking the appropriate button. 


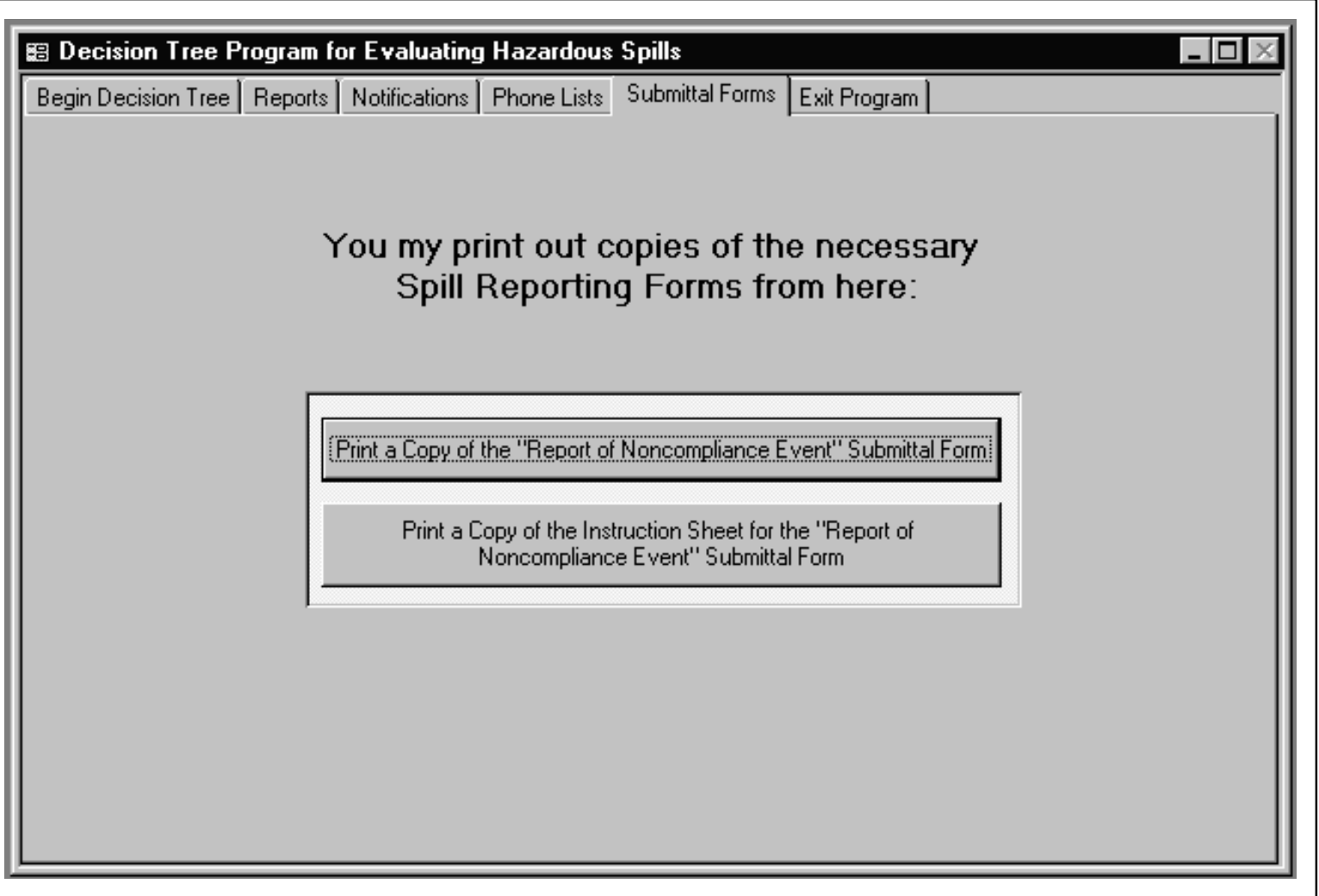

Figure 9. Submittal Forms screen. 


\section{Exit Program}

The last screen (Figure 10) is used to exit the program. Keep in mind that all SESSION results are lost once the program is exited. However, changes to phone lists or notification lists will be saved for subsequent sessions.

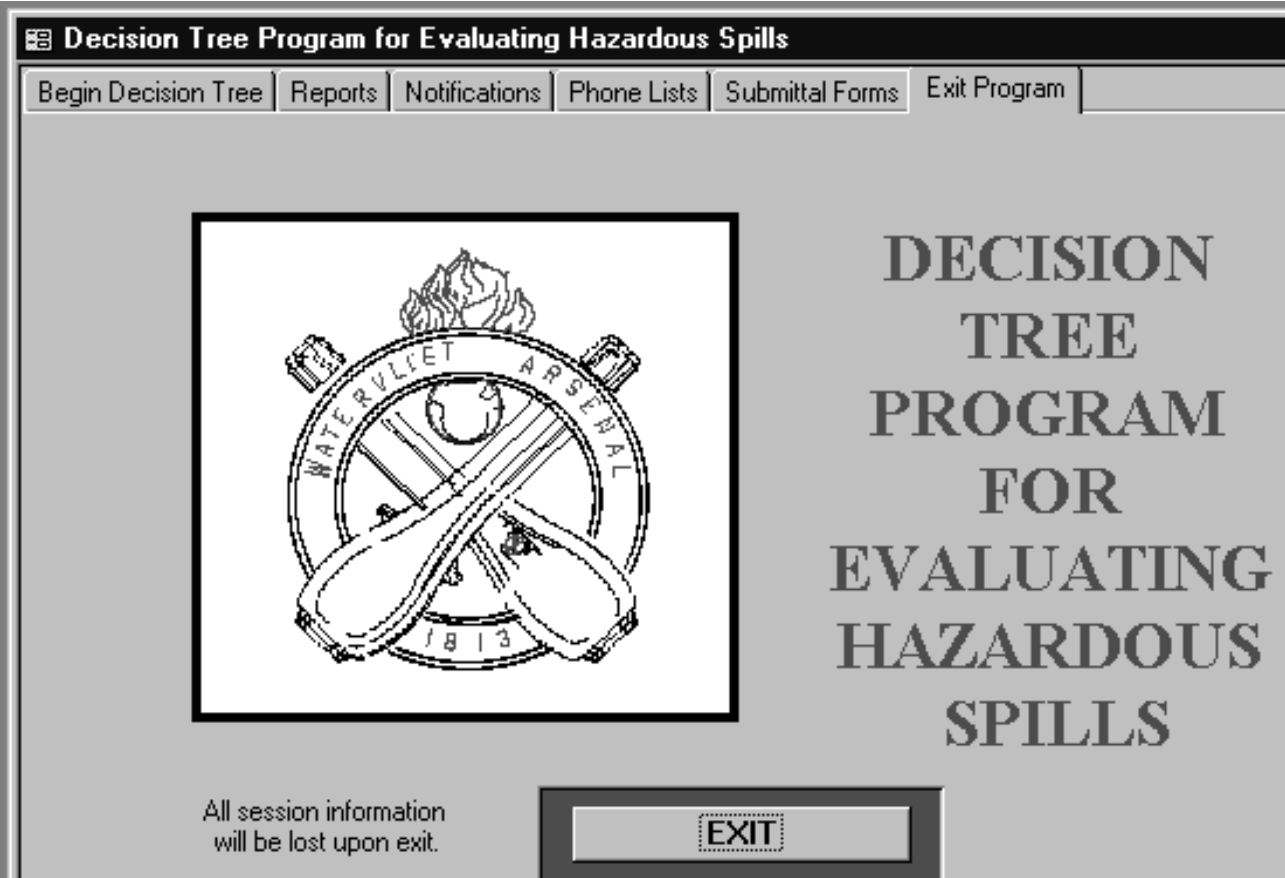

Figure 10. SPILL program Exit screen 


\section{Conclusion}

This study devised an automated approach to help Army installation personnel quickly and correctly evaluate hazardous materials spills, and make required notifications. The Decision Tree Program for Evaluating Hazardous Spills (SPILL) program is a computer tool designed to allow Watervliet Arsenal personnel to evaluate a material spill on installation property and, based on determining factors, to report the event in a proper and timely fashion to all appropriate authorities. While the SPILL program was created specifically to meet the needs of a single Army installation, it may help any installation that stores, handles, or uses hazardous materials to quickly and correctly evaluate and respond to hazardous materials spills. 


\section{Appendix A: List of Questions}




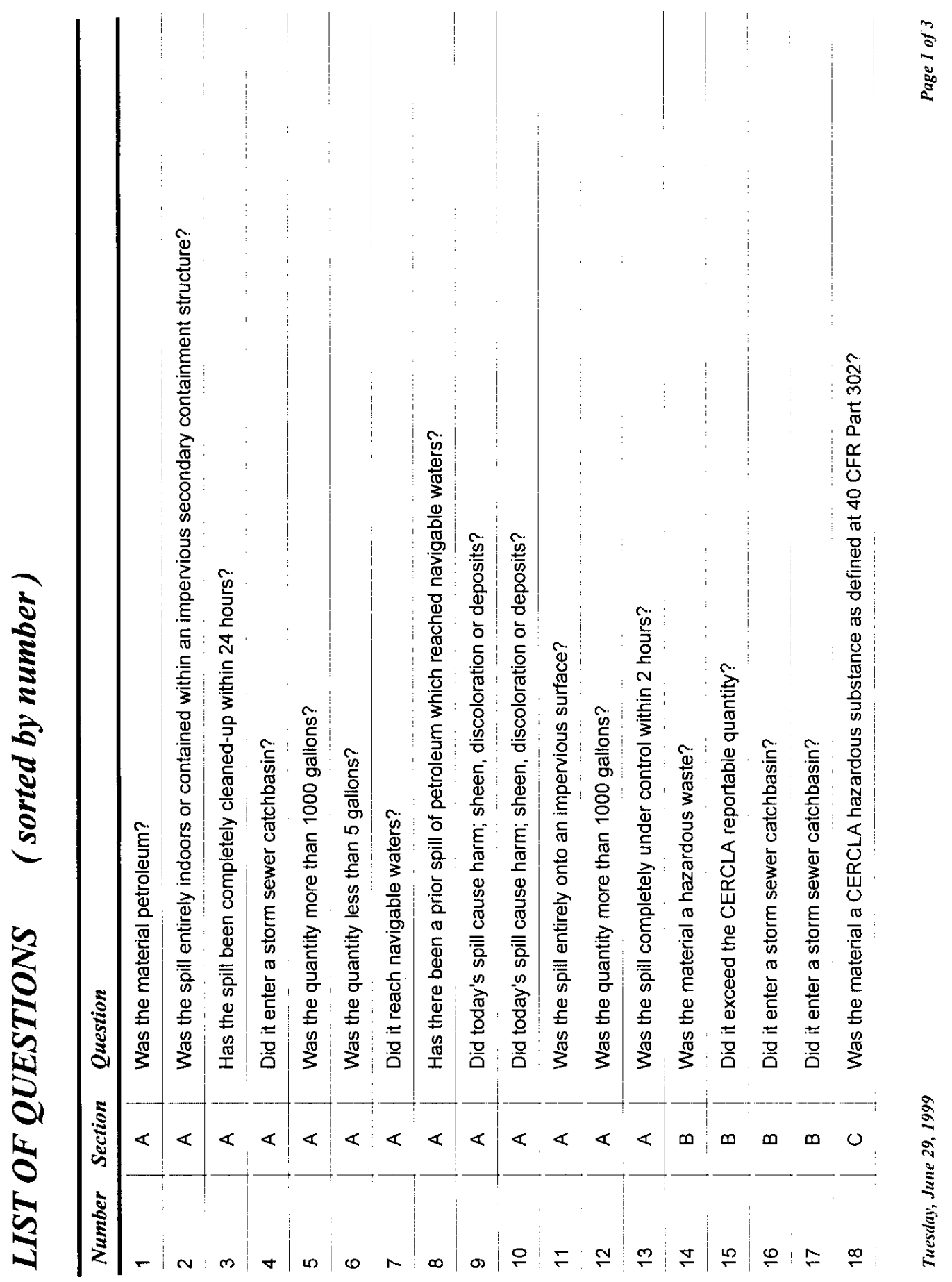




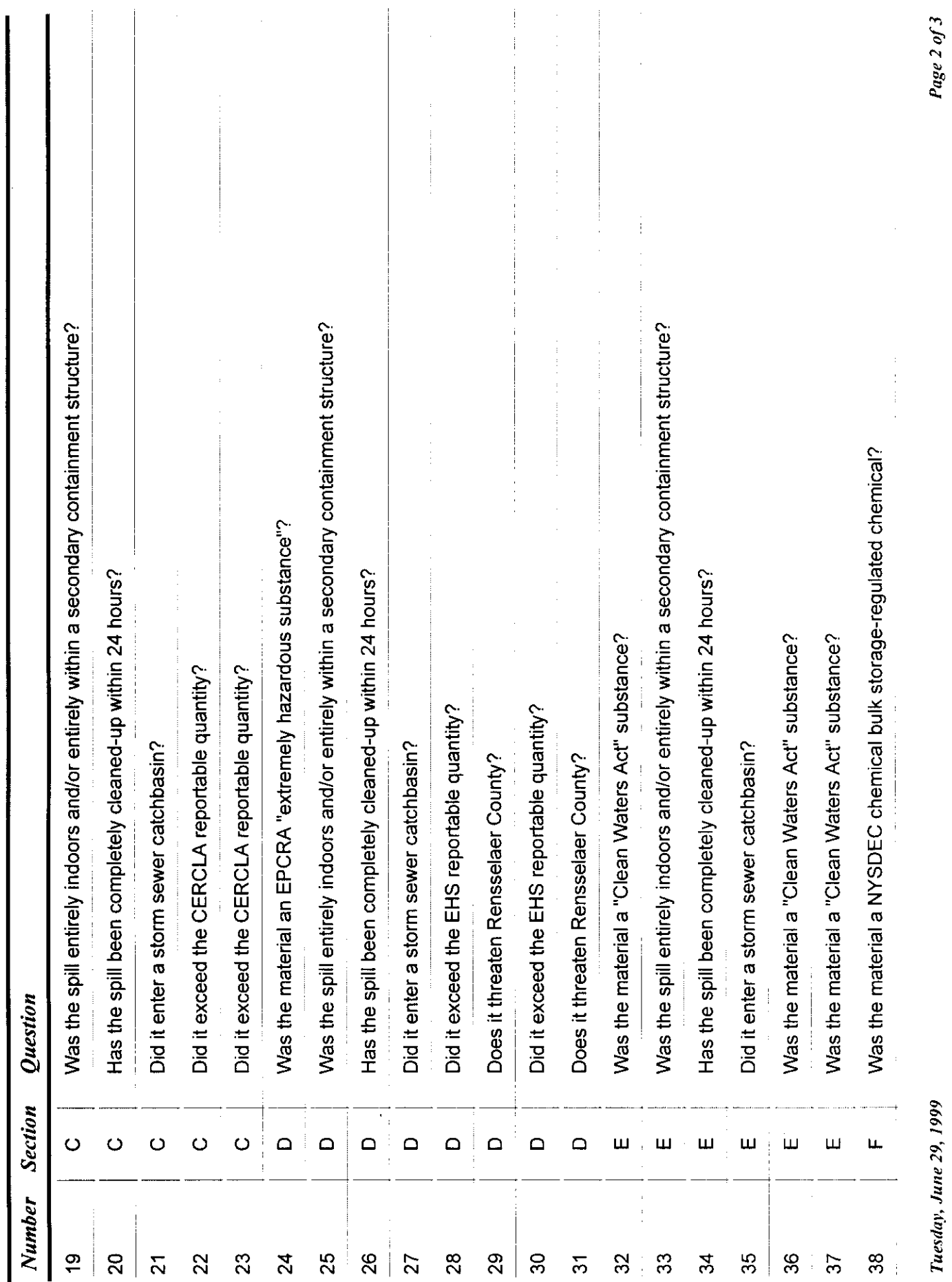




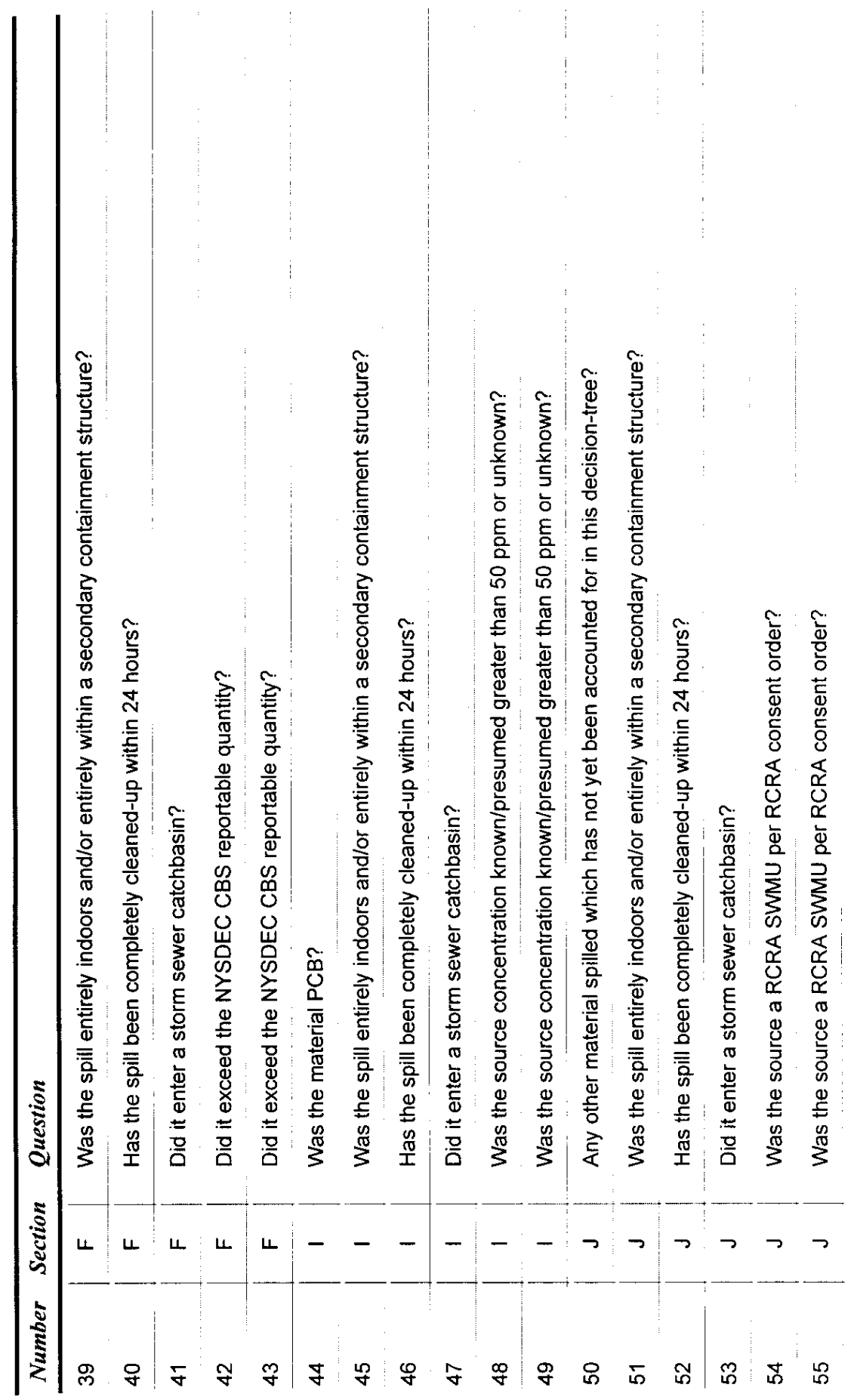

3
$\vdots$
3
8
8 


\section{Appendix B: System Road Map}




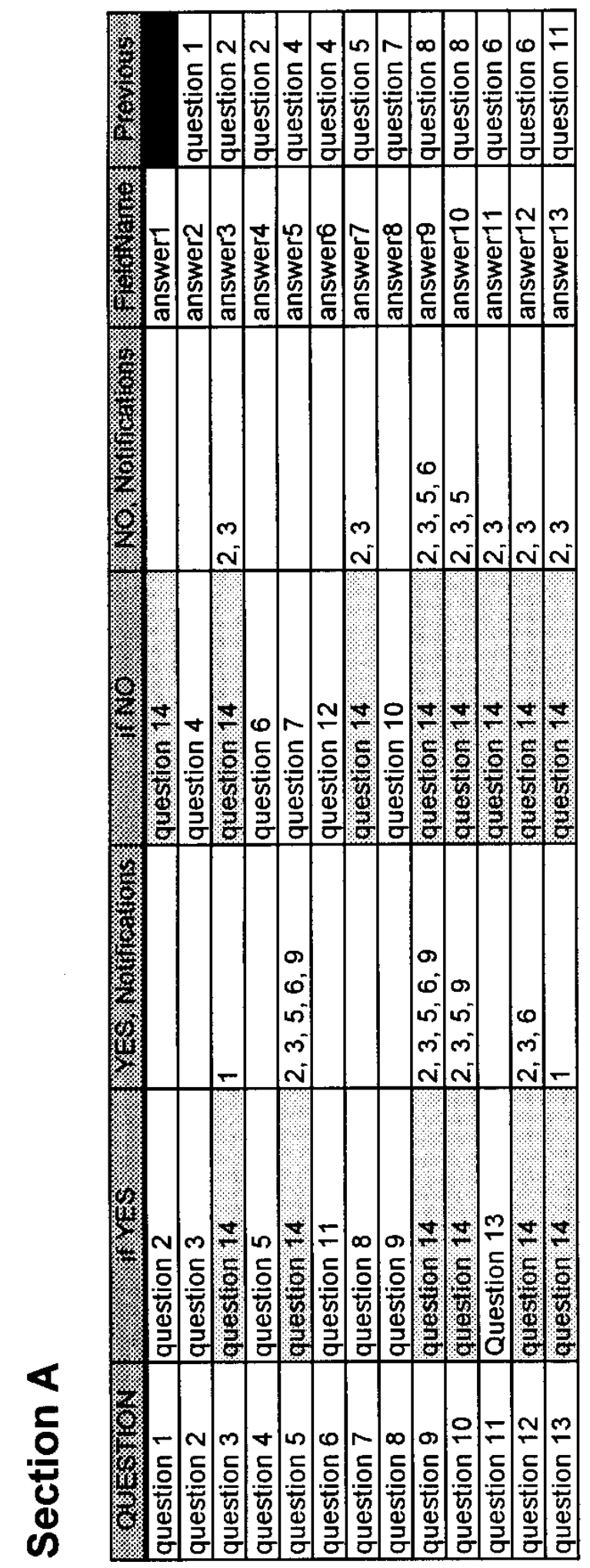




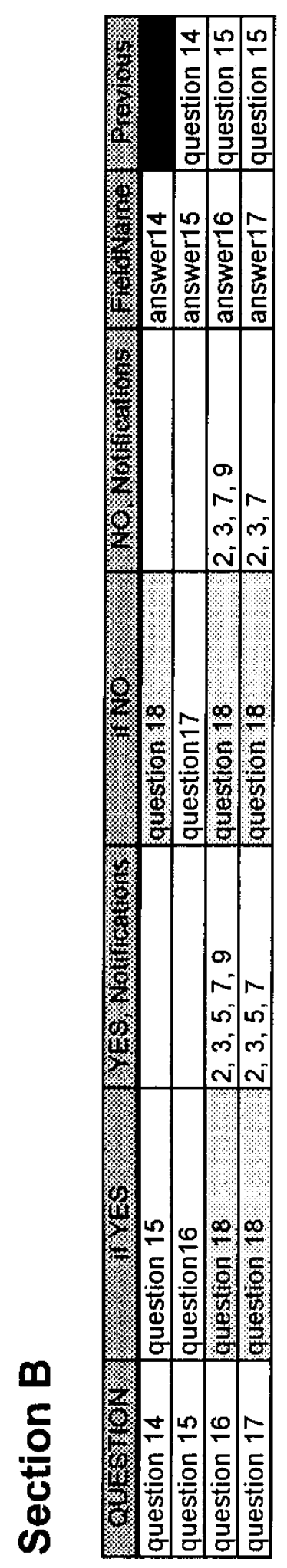




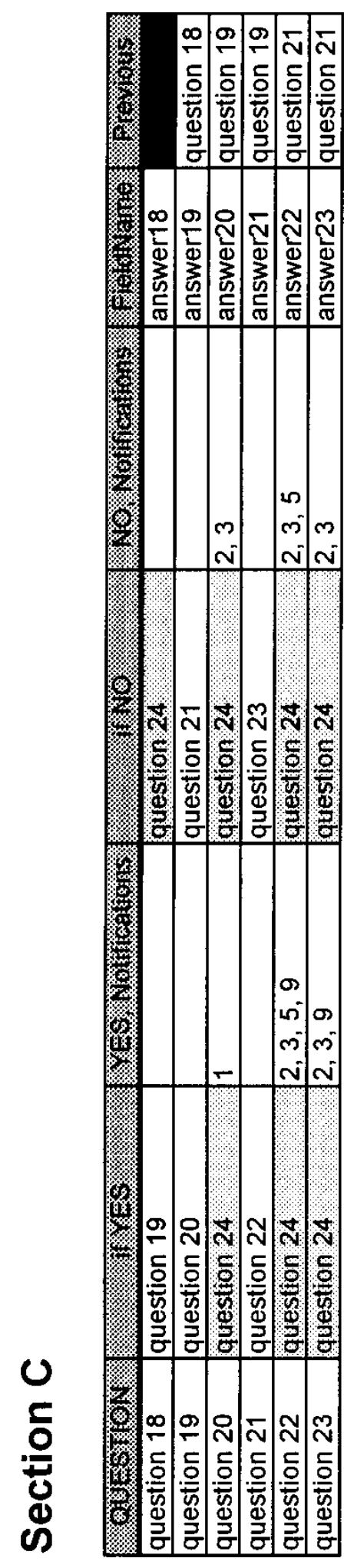




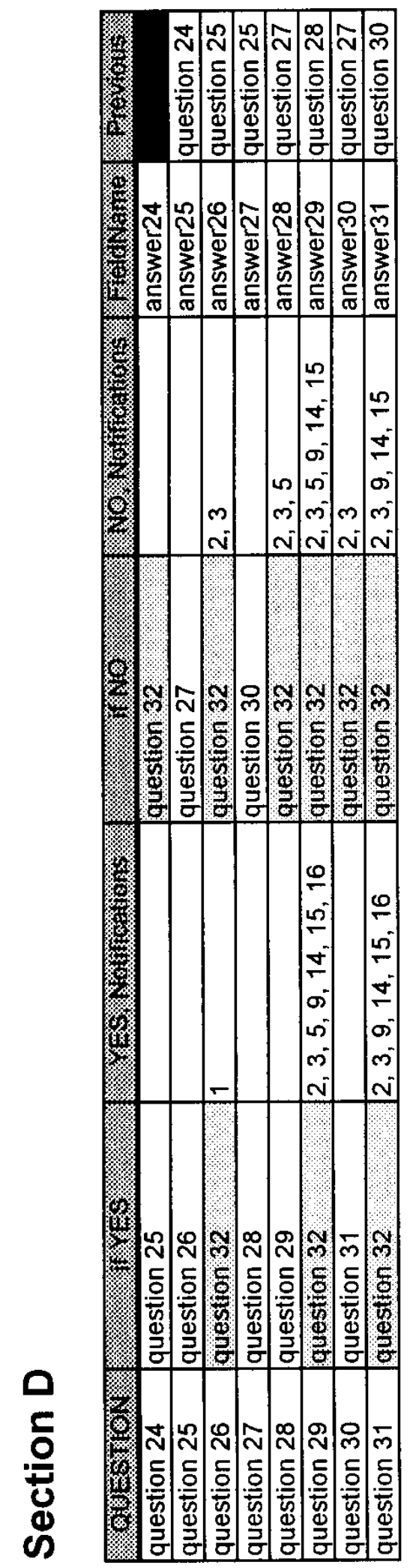




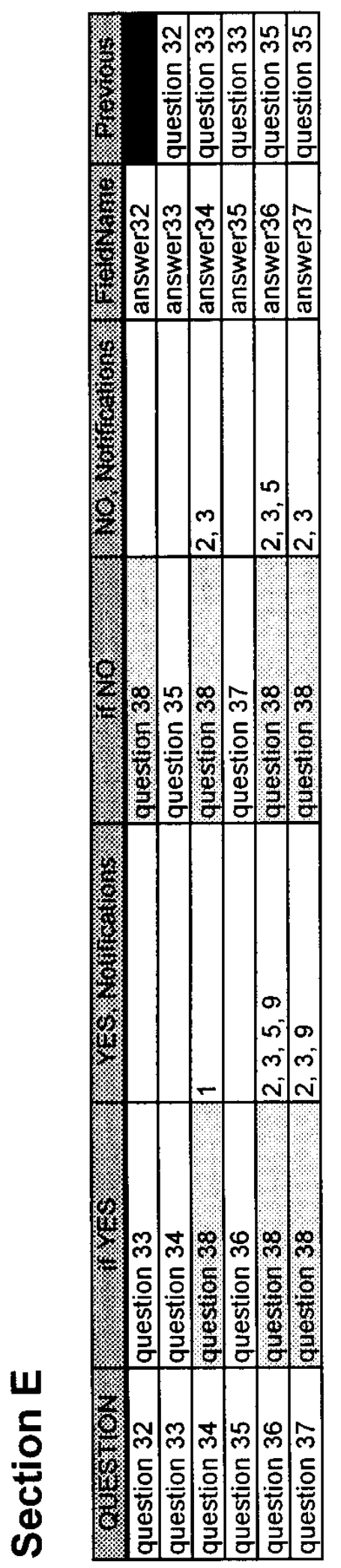




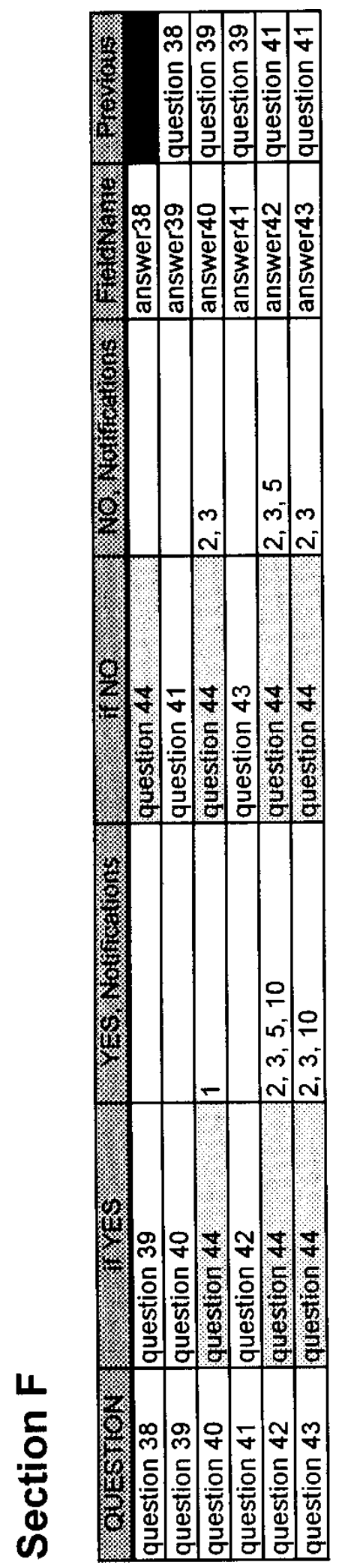




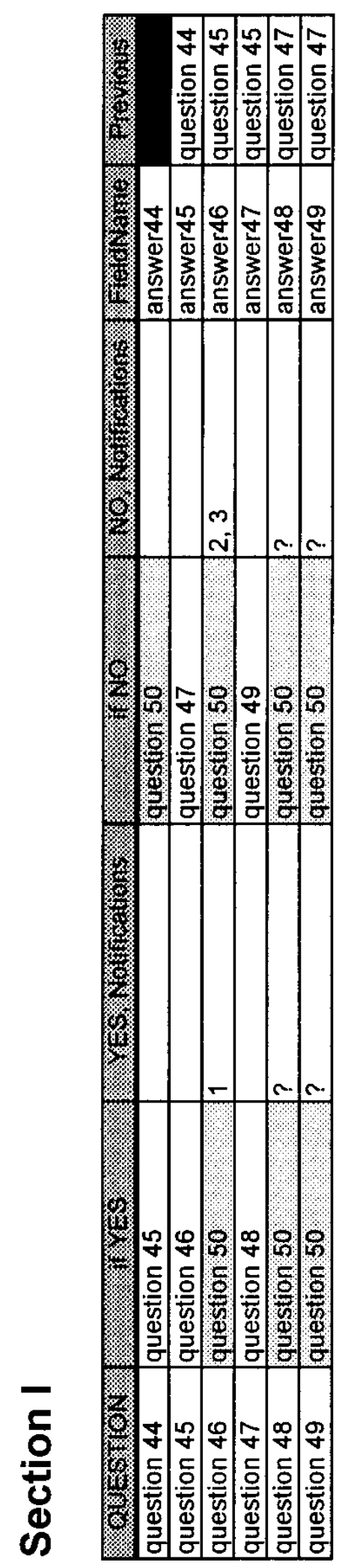




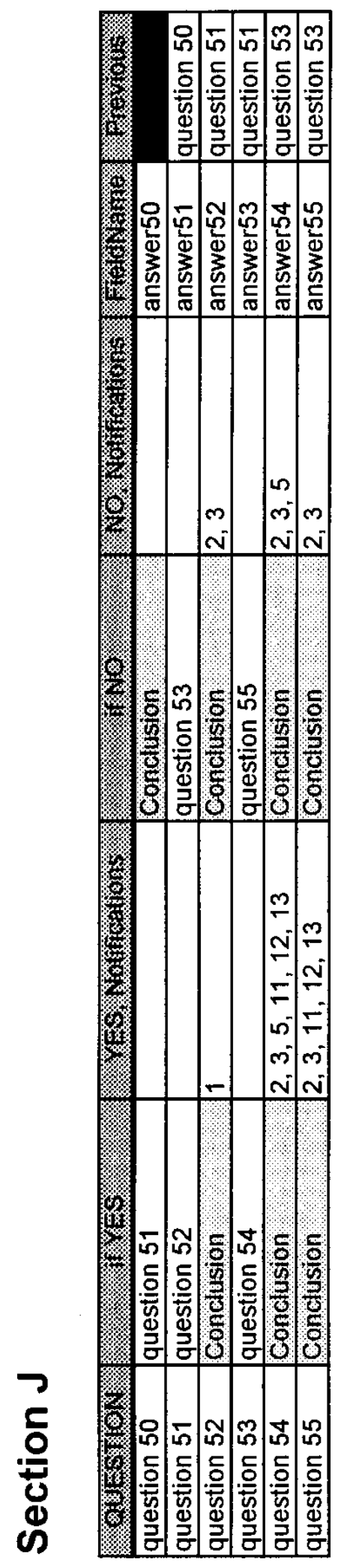




\section{Appendix C: Sample Notifications Report}




\section{NOTIFICATION ACTION REQUIRED:}

\section{Notification 1}

Send E-Mail to WVA personnel only. Send E-Mail "non-reportable spill" same day or next business day. See E-Mail distribution list.

\section{Notification 2}

Call NYSDEC Spill Hotline within 2 hours.

NYSDEL Spill Hotline Phone Number is (518) 457-7362.

\section{Notification 3}

Send E-Mail to HQ IOC and WVA personnel. Send E-Mail "Reportable Spill" same day or next business day. See E-Mail distribution list.

On the weekend, if high profile, call IOC duty officer at phone \#

\section{Notification 5}

Call NYSDEC Region 4 Regional Water Engineer (ATTN: Mr. Fred Sievers, P.E. ) at phone number (518) 357-2045. Ask if 5-day written letter is required or waived per NYSDEC discretion encoded at . Make written notation of decision in spill log book. If NYSDEC requires 5-day written letter, perform notification \#4. Alternate NYSDEC POCs are regional director or regional engineer or regional director.

\section{Notification 7}

Before "Re-commence Hazardous Waste Activities" call NYSDEC region 4 Regional Hazardous Waste Engineer (attn: Mr. Clif Van Guilder, P.E. at phone number, (518) 3572045 per 6 NYCRR 373-3.4 (g)(10). Include statements per 6 NYCRR 373-3.4 (g)(9). Alternate NYSDEC POC assistant regional director or regional engineer or regional director. Ask if 15-day written letter required or waived per NYSDEC discretion encoded at Make written notation of decision in spill log book. If NYSDEC require 15day written letter, perform notification \#8. 


\section{Notification 9}

Call the National Response Center (NRC) operated by the U.S. Coast Guard at phone number, _ , at the earliest convenience after termination of emergency response actions, or sooner if requesting assistance with emergency response actions. 


\section{Appendix D: Sample Answer Trail Report}




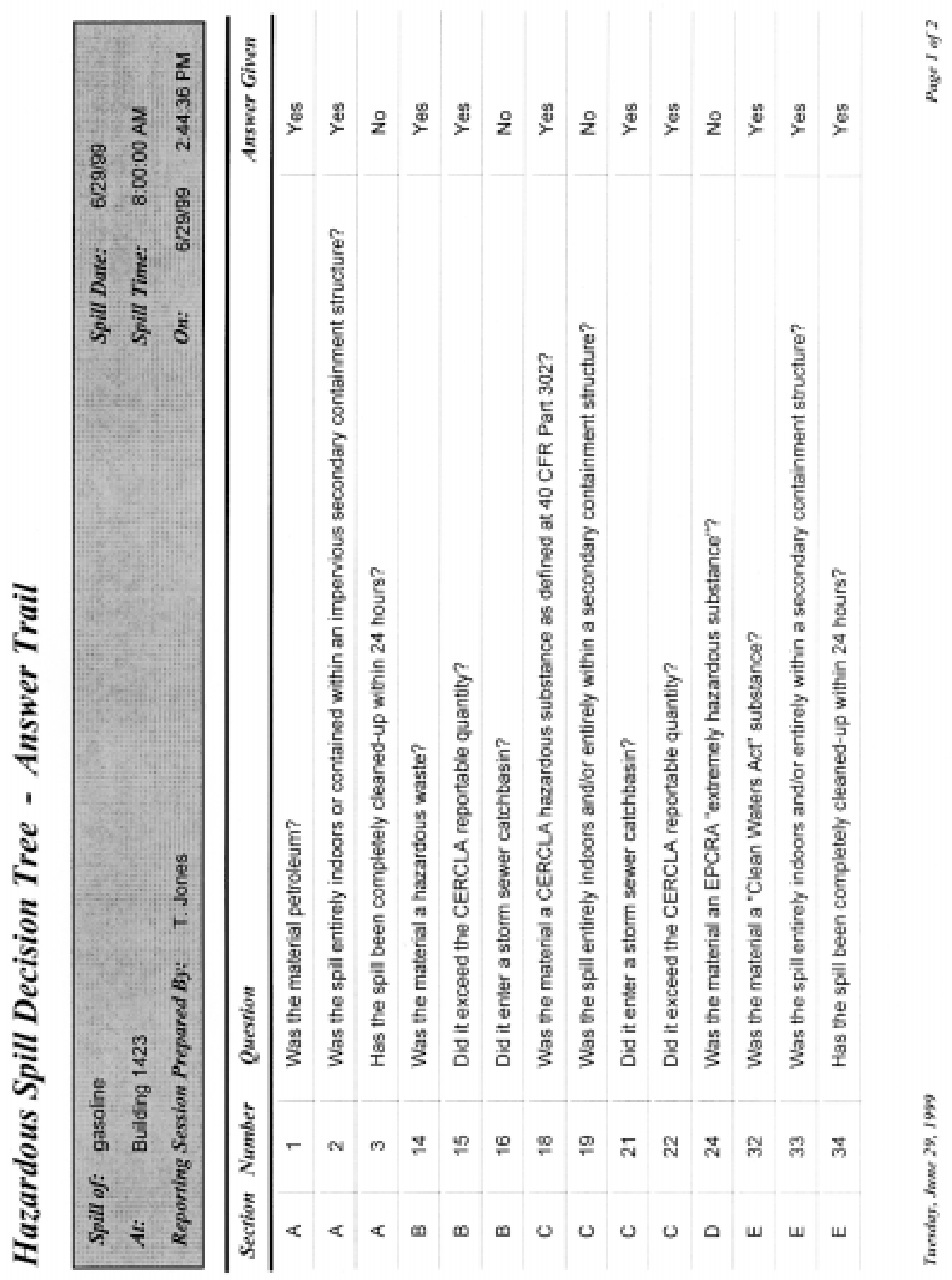




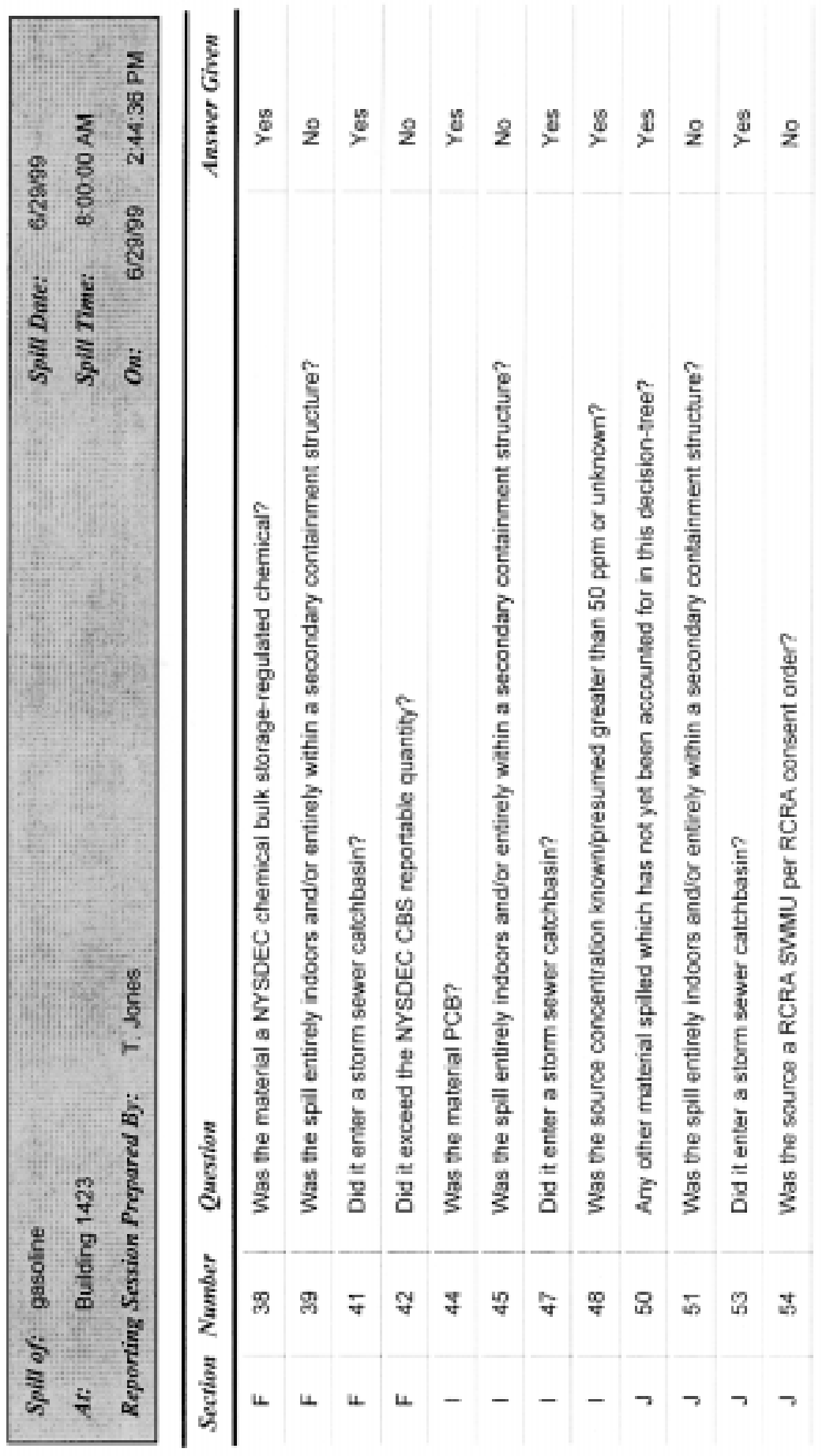

है

है 


\section{Appendix E: Report of Noncompliance Event Form}




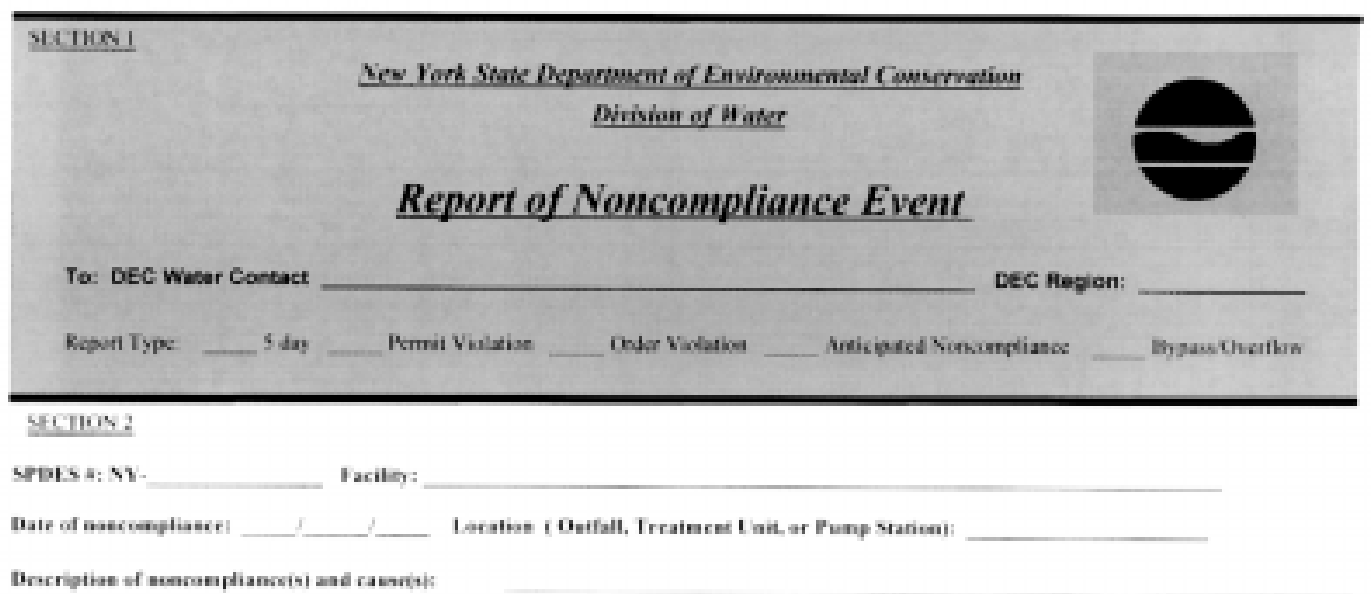

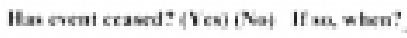

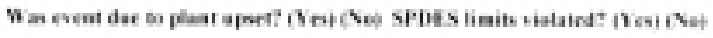
Start date, Biter of evrat

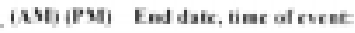
|ลงเบ|PM!

Daks, tion eral actificatise aade to BST: (M) (P) DEC Offirial rastaxict:

Inrectabe rarrextiec arthas:

Preventine ilene fere) sarrective actiem:

\section{SICTIE:}

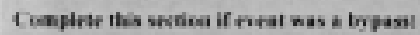

Hypas asetea!

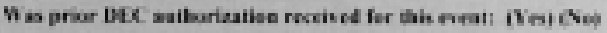
DEC Offkial ountaciet: Date of DEC appresal:

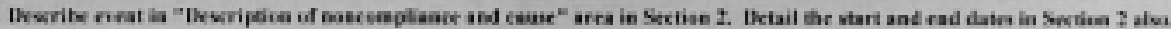

\section{SICTIRON4}

Facisty Heprescatatise! litk: Date:

Thaee a: 1 Fen $n$,

3506-101 (1203) 


\section{DISTRIBUTION}

Watervliet Arsenal, NY 12189-4050

ATTN: SIOWV-ISH (2)

Chief of Engineers ATTN: CEHEC-IM-LH (2) ATTN: HECSA Mailroom (2)

ATTN: CECC-R

ATTN: CERD-L ATTN: CERD-M

Defense Tech Info Center 22304 ATTN: DTIC-O (2) 


\section{REPORT DOCUMENTATION PAGE}

Form Approved OMB No. 0704-0188

Public reporting burden for this collection of information is estimated to average 1 hour per response, including the time for reviewing instructions, searching existing data sources, gathering and maintaining the data needed, and completing and reviewing the collection of information. Send comments regarding this burden estimate or any other aspect of this collection of Information, including suggestions for reducing this burden, to Washington Headquarters

Services, Directorate for information Operations and Reports, 1215 Jefferson Davis Highway, Suite 1204, Arlington, VA 22202-4302, and to the Office of
1. AGENCY USE ONLY (Leave Blank)
2. REPORT DATE
September 1999
3. REPORT TYPE AND DATES COVERED Final

4. TITLE AND SUBTITLE

Watervliet Arsenal Decision Tree Program for Evaluating Hazardous Spills (SPILL)

5. FUNDING NUMBERS

MIPR

8DISCERL19X

6. AUTHOR(S)

Veda D. Scarpetta

7. PERFORMING ORGANIZATION NAME(S) AND ADDRESS(ES)

U.S. Army Construction Engineering Research Laboratory (CERL)

P.O. Box 9005

Champaign, IL 61826-9005

8. PEFORMING ORGANIZATION REPORT NUMBER

TR 99/83

9. SPONSORING / MONITORING AGENCY NAME(S) AND ADDRESS(ES

Commander, Watervliet Arsenal

10. SPONSORING / MONITORING

ATTN: SIOWV-ISH

Building 20

Watervliet, NY 12189-4050

9. SUPPLEMENTARY NOTES

Copies are available from the National Technical Information Service, 5385 Port Royal Road, Springfield, VA 22161

12a. DISTRIBUTION / AVAILABILITY STATEMENT

12b. DISTRIBUTION CODE

Approved for public release; distribution is unlimited.

13. ABSTRACT (Maximum 200 words)

This study devised the Decision Tree Program for Evaluating Hazardous Spills (SPILL), a computer tool designed to allow Army installation personnel to evaluate a material spill on installation property and, based on determining factors, to report the event in a proper and timely fashion to all appropriate authorities. The program accomplishes the determination by presenting the user with a series of "YES" and "NO" questions regarding the spill. On conclusion of the question/answer segment, the program lists instructions and required notifications for the specific type of spill in question. SPILL also contains editable notification and phone lists.

While the SPILL program was created specifically to meet the needs of a single Army installation, it may help any installation that stores, handles, or uses hazardous materials to quickly and correctly evaluate and respond to hazardous materials spills.

\begin{tabular}{|c|c|c|}
\hline \multicolumn{3}{|l|}{ 14. SUBJECT TERMS } \\
\hline Watervliet Arsenal, NY & \multicolumn{2}{|l|}{ hazardous materials } \\
\hline Army facilities & \multicolumn{2}{|c|}{ Microsoft Access 97} \\
\hline cleanup & \multicolumn{2}{|c|}{ Decision Tree Program for Evaluating Hazardous S } \\
\hline $\begin{array}{l}\text { 17. SECURITY CLASSIFICATION } \\
\text { OF REPORT }\end{array}$ & $\begin{array}{l}\text { 18. SECURITY CLASSIFICATION } \\
\text { OF THIS PAGE }\end{array}$ & $\begin{array}{l}\text { 19. SECURITY CLASSIFICATION } \\
\text { OF ASTRACT }\end{array}$ \\
\hline Unclassified & Unclassified & Unclassified \\
\hline
\end{tabular}

